\title{
Description and validation of some European forest syntaxa - a supplement to the EuroVegChecklist
}

\author{
Wolfgang Willner ${ }^{1, *}$, Ayzik Solomeshch ${ }^{2}$, Andraž Čarni ${ }^{3}$, Erwin Bergmeier ${ }^{4}$, \\ Nikolai Ermakov ${ }^{5}$ \& Ladislav Mucina6, 7,8
}

\author{
Keywords: Abietetalia sibiricae, \\ Asaro europaei-Abietetea sibiricae, \\ Betulo pendulae-Populetalia tremulae, \\ Carpino-Fagetea, Quercetea ilicis, \\ Quercetea pubescentis, Quercetea \\ robori-sessiliflorae, Ural Mts., \\ Vaccinio-Piceetea.
}

Ključne besede: Abietetalia sibiricae, Asaro europaei-Abietetea sibiricae, Betulo pendulae-Populetalia tremulae, Carpino-Fagetea, Quercetea ilicis, Quercetea pubescentis, Quercetea robori-sessiliflorae, gorovje Ural, Vaccinio-Piceetea.

Received: 16. 2. 2015

Revision received: 21. 9. 2015

Accepted: 15. 10. 2015

\begin{abstract}
In this paper we present nomenclatural adjustments and validations of syntaxa of the forest vegetation of Europe. We introduce a new, valid name of the class of nemoral coniferous or mixed forests (Asaro europaei-Abietetea sibiricae) replacing the deciduous Carpino-Fagetea in the easternmost Europe and Siberia. We describe two new orders for birch and birch-poplar woodlands, formerly included in the Betulo pendulae-Populetalia tremulae. We validate the names of two alliances for the deciduous forests of the Southern Urals and the name of an alliance for hemiboreal forest swamps. The suballiance Ostryo-Tilienion, coined to accommodate the xerothermophilous ravine forests of SE Europe, is here elevated to the rank of alliance. Finally, we validate the name Quercion alnifoliae (evergreen oak forests of Cyprus).

\section{Izvleček}

V članku predstavljamo nomenklaturne prilagoditve in potrditve gozdnih sintaksonov Evrope. Predstavljamo novo veljavno ime razreda iglastih ali mešanih gozdov (Asaro europaei-Abietetea sibiricae), ki nadomešča listopadne gozdove razreda Carpino-Fagetea v najbolj vzhodnih delih Evrope in v Sibiriji. Opisali smo dva nova reda brezovih in brezovo-topolovih gozdov, ki sta bila prej vključena v red Betulo pendulae-Populetalia tremulae. Veljavno smo opisali dve zvezi listopadnih gozdov v južnem Uralu in poimenovali zvezo hemiborealnih močvirnih gozdov. Podzvezo Ostryo-Tilienion, kamor uvrščamo kserotermofilne gozdove plementih listavcev jugovzhodne Evrope, smo povzdignili na nivo zveze. Nazadnje smo veljavno opisali zvezo Quercion alnifoliae (vednozeleni hrastovi gozdovi na Cipru).
\end{abstract}

Abbreviation and nomenclature: ICPN - International Code of Phytosociological Nomenclature, 3rd ed. (Weber et al. 2000); nomenclature of plant species follows Euro+Med PlantBase (www.emplantbase.org, last accessed on 26 Jan 2015). In cases where the taxa are not covered by the Euro+Med checklist, we use the latest taxonomic and nomenclatural sources as implemented in the EuroVegChecklist (Mucina et al., submitted).

\footnotetext{
1 Vienna Institute for Nature Conservation \& Analyses (VINCA), Giessergasse 6/7, A-1090 Wien, Austria. E-mail: wolfgang.willner@vinca.at * Corresponding author

2 Department of Plant Sciences, University of California Davis, One Shields Ave., Davis, CA 95616, USA. E-mail: aizsolomeshch@ucdavis.edu

3 Institute of Biology, Scientific Research Center of the Slovenian Academy of Sciences and Arts, Novi trg 2, SI-1001 Ljubljana, Slovenia. E-mail: carni@zrc-sazu.si

4 Albrecht-von-Haller Institute of Plant Sciences, University of Göttingen, Untere Karspüle 2, D-37073 Göttingen, Germany. E-mail: erwin.bergmeier@bio.unigoettingen.de

5 Central Siberian Botanical Garden, Russian Academy of Sciences, Zolotodolinskaya 101, Novosibirsk 630090, Russian Federation. E-mail: brunnera@mail.ru

6 Iluka Chair in Vegetation Science and Biogeography, School of Plant Biology, The University of Western Australia, 35 Stirling Hwy, Crawley WA 6009, Perth, Australia. E-mail: laco.mucina@uwa.edu.au

7 Department of Geography \& Environmental Studies, Stellenbosch University, Private Bag X1, Matieland 7602, Stellenbosch, South Africa

8 Department of Botany and Microbiology, College of Science, King Saud University, P.O. Box 2455, Riyadh 11451, Saudi Arabia
} 


\section{Introduction}

This paper is part of a series of contributions accompanying the publication 'Vegetation of Europe: Hierarchical floristic classification system of vascular plant, bryophyte, lichen, and algae communities' (Mucina et al. submitted; hereafter referred to as 'EuroVegChecklist'). During the preparation of this checklist, it became apparent that for several syntaxa no valid or legitimate names according to the International Code of Phytosociological Nomenclature (Weber et al. 2000; ICPN hereafter) were available. In exceptional cases it was also necessary to establish new high-ranked units to increase the coherence of the classification scheme.

In the present paper, we describe and validate forest syntaxa belonging to the classes Quercetea robori-sessiliflorae, Quercetea pubescentis, Carpino-Fagetea, Quercetea ilicis and Vaccinio-Piceetea. We also introduce a new, valid name of the class of nemoral coniferous or mixed forests replacing the deciduous Carpino-Fagetea in the easternmost Europe and Siberia. The presentations of the syntaxa are the responsibility of the authors named in the respective subheadings. When quoting them, please cite '<author(s)> in Willner et al. 2016'.

\section{Description and validation of syntaxa}

\section{Acidophilous atlantic birch woodlands of Western and Southern Europe}

(by W. Willner \& L. Mucina)

The birch woodlands (Betulion fontquerio-celtibericae Rivas-Martínez et Costa 2002 and Lonicero periclymeniBetulion pubescentis Géhu 2006) of the Atlantic region of Europe have been classified within the Betulo pendulaePopuletalia tremulae Rivas-Martínez et Costa 2002 (see Rivas-Martínez et al. 2002, Géhu 2006). However, we consider the concept of this order as being too heterogeneous in terms of biogeography, ecology, and also of species composition. The atlantic birch woodlands are usually dominated by Betula pubescens s. 1. (including $B$. celtiberica) and neither by Betula pendula s. 1. (including B. fontqueri) nor Populus tremula that are diagnostic for the temperate deciduous birch-poplar woodlands on mineral soils (see below). They also cannot be included in the Quercetalia roboris because the latter represent the zonal oak forests on nutrient-poor acidic soils of Europe while the birch woodlands are considered successional stages replacing oak forests after disturbance or permanent communities in frequently disturbed habitats, such as avalanche channels. Therefore, we establish a new order for the acidophilous birch communities of the Atlantic region:

\section{Lonicero periclymeni-Betuletalia pubescentis Willner et Mucina ord. nov. hoc loco \\ (Quercetea robori-sessiliflorae) \\ Holotypus hoc loco: Lonicero periclymeni-Betulion pubescen- tis Géhu 2006 (Géhu 2006: 299) \\ Diagnostic taxa: Betula pubescens (incl. B. celtiberica), Blechnum spicant, Dryopteris dilatata, Lonicera pericly- menum, Osmunda regalis, Pteridium aquilinum}

We classify this order in the Quercetea robori-sessiliflorae. However, it also shows affinities to the birch woodlands on mesotrophic mires (Salici pentandrae-Betuletalia pubescentis Clausnitzer in Dengler et al. 2004 and Molinio-Betuletalia pubescentis Passarge 1968) that are classified in the Alnetea glutinosae in the EuroVegChecklist. If the dominant species of the tree layer is given a higher weight in the classification, the latter two orders could be combined with the Lonicero periclymeni-Betuletalia pubescentis into the Molinio-Betuletea pubescentis Passarge 1968 (in case this class would be considered a viable syntaxonomic concept). A large-scale syntaxonomic revision is needed to evaluate the merits of these two alternative class concepts.

\section{Temperate deciduous birch- poplar woodlands on mineral soils of Europe}

(by W. Willner \& L. Mucina)

This unit comprises natural pioneer and secondary birchpoplar woodlands on mineral soils in the temperate zone of Europe. Rivas-Martínez et al. (2002) included these woodlands in the Betulo pendulae-Populetalia tremulae Rivas-Martínez et Costa 2002. However, the type alliance of this order, the Corylo-Populion tremulae (Br.-Bl. ex O. de Bolòs 1973) Rivas-Martínez et Costa 1998, is based on the Hepatico-Coryletum Br.-Bl. 1952. In the EuroVegChecklist hazel scrubs are excluded from this unit and classified within the Crataego-Prunetea Tx. 1962. Therefore, it seems necessary to establish a new name for the alliance and for the order of the mesic birch-poplar woodlands. Unfortunately, only few associations corresponding 
to this vegetation type have been formally described so far (e.g., De Bolòs 1979) and a large-scale comparison is completely missing. Therefore, we refrain from a formal description of the higher syntaxa until more data from different parts of Europe have been gathered.

\section{Fragario vescae-Populetalia tremulae Willner et $\mathrm{Mu}$ - cina ordo nov. prov.}

(Brachypodio pinnati-Betuletea pendulae)

Diagnostic species: Betula pendula, Populus tremula, Salix caprea

The tree species composition of this provisional order resembles the forests that dominated large parts of temperate Europe in the early Holocene, before the CarpinoFagetea species returned from their glacial refugia. Similar woodlands can still be found in the hemiboreal zone of the Southern Urals and Southern Siberia (Ermakov et al. 2000; Chytrý et al. 2010). Therefore, the Fragario vescaePopuletalia tremulae should be classified within the Brachypodio pinnati-Betuletea pendulae Ermakov et al. 1991, a class originally described from Southern Siberia (Ermakov et al. 2000).

\section{Thermophilous oak woodlands of the Southern Urals}

(by A. Solomeshch)

\section{Lathyro pisiformis-Quercion roboris Solomeshch et Grigoriev all. nov. hoc loco \\ (Quercetalia pubescenti-petraeae, Quercetea pubescentis)}

Synonyms: Lathyro pisiformis-Quercion roboris Solomeshch et al. 1989 (ICPN art. 1); Pruno-Quercion roboris Schubert et al. 1979 (ICPN art. 5)

Holotypus hoc loco: Brachypodio pinnati-Quercetum roboris Solomeshch et Grigoriev in Willner et al. 2016 (see below)

Diagnostic taxa: Trees \& shrubs: Quercus robur, Caragana frutex, Rosa majalis; Herbs and graminoids: Aconitum anthora, Carex pediformis subsp. macroura, Digitalis grandiflora, Geranium pseudosibiricum, G. sylvaticum, Heracleum sphondylium subsp. sibiricum, Hieracium pseuderectum, Lathyrus gmelinii, Lathyrus rotundifolius, L. pisiformis, L. sylvestris, Pleurospermum uralense, Seseli libanotis, Vicia sepium

The Lathyro pisiformis-Quercion roboris comprises thermophilous continental oak woodlands on the very eastern border of the Quercus robur distribution in the
Southern Urals, close to the border between the Eastern Europe and the Western Siberia. They occur in the forest-steppe zone on fertile dark grey soils over calcareous substrate and often are surrounded by steppe vegetation. These woodlands are floristically rich and contain in the ground layer thermophilous species such as Brachypodium pinnatum, Campanula bononiensis, Clinopodium vulgare, Filipendula vulgaris, Inula hirta, I. salicina, Nepeta pannonica, Origanum vulgare, Phlomis tuberosa, Polygonatum odoratum, Tanacetum corymbosum, Stachys officinalis, Vincetoxicum hirundinaria and Viola hirta, which differentiate these forest from the mesophilous forests of the Carpinetalia betuli P. Fukarek 1968 (class CarpinoFagetea). These species are considered as diagnostic for the Quercetalia pubescenti-petraeae Klika 1933 (Zólyomi 1957; Chytrý 1997). However, the Southern Urals oak woodlands are not typical of this order because of their distribution far outside the ranges of Quercus pubescens and Q. petraea and because of the absence of many species typical of the Quercetalia pubescenti-petraeae, such as Crataegus laevigata, Sorbus torminalis, Viburnum lanata, Dictamnus albus, Ligustrum vulgare and Melittis melissophyllum. The most similar alliance is the Aceri tatariciQuercion Zólyomi 1957 (see Bulokhov \& Solomeshch 2003). Towards the East, these oak woodlands give way to the Siberian forests of the hemi-boreal Brachypodio pinnati-Betuletea pendulae that can be floristically similar in the ground layer. However, in the canopy of the hemi-boreal forests, Quercus robur is replaced by Pinus sylvestris, Betula pendula and Larix sibirica (Ermakov et al. 1991; Solomeshch et al. 2002).

The Lathyro pisiformis-Quercion roboris includes half a dozen associations described in a manuscript registered in then Soviet Union Institute of Scientific and Technical Information (VINITI; Solomeshch et al. 1989a). Other associations of this alliance were published by Solomeshch et al. (1994), Martynenko et al. (2005, 2008a, 2008b) and Shirokikh et al. (2010). This alliance has not been validated so far since the VINITI manuscripts (incl. Solomeshch et al. 1989a) were (erroneously) considered as effective publication by some Russian phytosociologists. Here we validate the alliance and one of its associations:

\section{Brachypodio pinnati-Quercetum roboris Solomeshch et Grigoriev ass. nov. hoc loco \\ (Lathyro pisiformis-Quercion roboris, Quercetalia pubescen- ti-petraeae)}

Holotypus (hoc loco) of the association: Russian Federation, Bashkortostan Republic, Kugarchinskiy District, $5 \mathrm{~km}$ NE from the village Nizhnebikkuzino. Coordi- 
nates: 5259’18.2” N, 56³4'15.3” E. Field code: 101. Habitat: mountain ridge slope, close to the top of the ridge. Relevé area: $300 \mathrm{~m}^{2}$, Aspect: East; Cover of tree layer: 70\%; Cover of shrub layer: 7\%; Cover of herb layer: 75\%; Cover of moss layer: 0\%; Average height of trees: $10 \mathrm{~m}$; Average diameter of tree trunks: 30 $\mathrm{cm}$. Species cover-abundance values are given in the modified Braun-Blanquet scale. Also published in Shirokikh et al. (2010: 336-344, Table 36, rel. 7). Author of the relevé: Ayzik Solomeshch.

Tree layer: Quercus robur 5, Acer platanoides 1, Quercus robur 1, Ulmus glabra +, Betula pendula r, Sorbus aucuparia $\mathrm{r}$, Tilia cordata $\mathrm{r}$.

Shrub layer: Caragana frutex 1, Cytisus ruthenicus 1, Euonymus verrucosa + , Rosa majalis + , Prunus fruticosa + , Rhamnus cathartica $\mathrm{r}$, Viburnum opulus $\mathrm{r}$.

Herb layer: Aegopodium podagraria 2b, Brachypodium pinnatum 2b, Rubus saxatilis 2b, Phlomis tuberosa 1, Quercus robur juv. +, Aconogonon alpinum +, Adenophora liliifolia +, Agrimonia eupatoria subsp. asiatica +, Artemisia armeniaca + , Artemisia vulgaris + , Bistorta officinalis +, Calamagrostis arundinacea + , C. epigejos + , Campanula bononiensis + , Carex praecox + , Crepis sibirica +, Dactylis glomerata +, Delphinium dictyocarpum +, Digitalis grandiflora +, Euphorbia semivillosa +, Filipendula vulgaris +, Fragaria viridis +, Galatella sedifolia subsp. biflora +, Galium boreale +, G. ruthenicum +, Geranium pseudosibiricum +, G. sanguineum +, Geum urbanum +, Heracleum sphondylium subsp. sibiricum +, Inula salicina + , Klasea radiata subsp. gmelinii + , Lathyrus pisiformis +, Melica nutans +, Nepeta pannonica +, Origanum vulgare +, Primula veris subsp. macrocalyx + , Pteridium aquilinum + , Sanguisorba officinalis + , Senecio nemorensis + , Seseli libanotis +, Solidago virgaurea +, Stachys officinalis + , Stellaria holostea + , Tanacetum corymbosum +, Thalictrum minus +, Trifolium medium +, Veronica spuria +, V. teucrium +, Vicia cracca +, V. sepi$u m+$, Viola hirta +, V. mirabilis +, V. odorata +, Achillea millefolium $\mathrm{r}$, Aconitum anthora $\mathrm{r}$, Adonis vernalis $\mathrm{r}$, Artemisia absinthium r, A. sericea r, Asarum europaeum r, Asparagus officinalis r, Asperula tinctoria r, Bupleurum longifolium r, Campanula persicifolia r, C. trachelium r, Carex spicata r, Dianthus versicolor r, Elytrigia repens r, Fallopia convolvulus r, Festuca valesiaca subsp. parviflora r, Galium odoratum r, Hieracium umbellatum r, Hylotelephium telephium r, Lathyrus rotundifolius r, L. pratensis r, Medicago falcata r, Orobanche alsatica r, Phleum pratense $\mathrm{r}$, Poa pratensis $\mathrm{r}, P$. transbaicalica $\mathrm{r}$, Serratula coronata $\mathrm{r}$, Tragopogon orientalis $\mathrm{r}$, Trifolium lupinaster r, Verbascum nigrum r, Vincetoxicum albovianum $\mathrm{r}$.

\section{Broad-leaved deciduous forests of the Southern Urals}

(by A. Solomeshch)

\section{Aconito lycoctoni-Tilion cordatae Solomeshch et Gri- goriev all. nov. hoc loco}

(Carpinetalia betuli, Carpino-Fagetea sylvaticae)

Synonym: Aconito septentrionalis-Tilion cordatae Solomeshch et al. 1993 (ICPN art. 1)

Holotypus hoc loco: Stachyo sylvaticae-Tilietum cordatae Martynenko et al. 2005 (Martynenko et al. 2005)

Diagnostic taxa: Tilia cordata; Aconitum lycoctonum (=A. septentrionale), Anemone altaica, Bromopsis benekenii, Bupleurum longifolium, Campanula latifolia, Crepis sibirica, Drymochloa sylvatica, Geranium robertianum, Heracleum sphondylium subsp. sibiricum, Lactuca macrophylla subsp. uralensis, Lamium album, Parasenecio hastatus, Pleurospermum uralense, Stellaria bungeana

This alliance represents zonal broad-leaved deciduous forests of the Southern Urals. They occur on mesic rich grey forest soils of upland flat terrains, on slopes of different steepness and aspect, as well as on high riverine terraces. Tilia cordata predominates in the tree layer. Other trees such as Quercus robur, Ulmus glabra, Acer platanoides, Populus tremula and Prunus padus are typically present with lower abundance. Shrubs such as Corylus avellana, Daphne mezereum, Euonymus verrucosa, Lonicera xylosteum and Salix caprea form the shrub layer. Species characteristic of the Carpino-Fagetea and of the Carpinetalia betuli (e.g. Asarum europaeum, Dryopteris filix-mas, Galium odoratum, Lathyrus vernus, Pulmonaria obscura, Stellaria holostea, Viola mirabilis etc.) prevail in the herb layer. A group of species of Euro-Siberian distribution is represented by Aconitum lycoctonum, Crepis sibirica, Parasenecio hastatus, Stellaria bungeana and others. The alliance has the following distinguishing features: (i) presence of species of Siberian and Ural flora such as Anemone altaica, Crepis sibirica, Parasenecio hastatus, Pleurospermum uralense and Stellaria bungeana; (ii) absence of European trees such as Carpinus betulus, Acer pseudoplatanus, Fagus sylvatica and Quercus petraea and of herbaceous plants such as Convallaria majalis, Festuca heterophylla, Hepatica nobilis, Lamium galeobdolon and Mercurialis perennis; (iii) absence of coniferous species such as Picea obovata and Abies sibirica in the tree layer as well as absence of boreal herbaceous species such as Vaccinium vitis-idaea, V. myrtillus, Trientalis europaea, Maianthemum bifolium, Luzula pilosa, Goodyera repens and of boreal mosses such as Pleurozium schreberi, Hylocomium splendens and Dicranum scoparium. 
The alliance includes two associations:

\section{Stachyo sylvaticae-Tilietum cordatae Martynenko et al. 2005}

Syn.: Aegopodio podagrariae-Tilietum cordatae Schubert, Jäger et Mahn 1979 (ICPN art. 5); Aegopodio-Tilietum Schubert, Jäger et Mahn ex Mirkin et Solomeshch 1990 (ICPN art. 1)

\section{Brachypodio pinnati-Tilietum cordatae Grigoriev ex Martynenko et al. 2005}

Syn.: Brachypodio pinnati-Tilietum cordatae Grigoriev in Solomeshch et al. 1989 (ICPN art. 1).

The forest stands classified in these associations were described from the Southern Urals by Gorchakovskii (1972), Schubert et al. (1979), Solomeshch et al. (1989b, 1994) and Mirkin \& Solomeshch (1990). None of the earlier published names was valid. Gorchakovskii (l.c.) used the Russian typological approach and provided neither an appropriate name nor a sufficient original diagnosis for the association. Schubert et al. (1979) did not provide the nomenclature type. An attempt to validate the Aegopodio-Tilietum by publishing its nomenclature type (Mirkin \& Solomeshch 1990) was not successful because this publication was not effective (ICPN art. 1). Thus, the first valid publication of the names for these two associations appeared in Martynenko et al. (2005).

The Stachyo sylvaticae-Tilietum cordatae Martynenko et al. 2005 is chosen as the typus for the Aconito lycoctoniTilion cordatae. Since the book by Martynenko et al. (2005) might not be easily available for all readers, we present here the relevé that was chosen as the holotypus of this association:

Russian Federation, Bashkortostan Republic, Burzjanskiy District; flat top of a mountain ridge. Approx. coordinates: $53^{\circ} 08^{\prime}$ N, $56^{\circ} 55^{\prime}$ E; Relevé area: $1000 \mathrm{~m}^{2}$; Cover of tree layer: $85 \%$; Cover of shrub layer: $1 \%$; Cover of herb layer: 65\%; Average tree height: $26 \mathrm{~m}$; Average diameter of tree trunks: $30 \mathrm{~cm}$. Species cover-abundance values are given in the original Braun-Blanquet scale. Sampled in 2002. Field code: 305. Author of the relevé: V.B. Martynenko.

Tree layer: Tilia cordata 4, Acer platanoides 3, A. platanoides 2, Prunus padus 2, Ulmus glabra 2, Betula pendula + , Sorbus aucuparia $\mathrm{r}$.

Shrub layer: Rubus idaeus +, Lonicera xylosteum r.

Herb layer: Aegopodium podagraria 3, Aconitum lycoctonum 2, Crepis sibirica 2, Milium effusum 1, Pteridium aquilinum 1, Urtica dioica 1, Anthriscus sylvestris +, Asarum europaeum +, Campanula latifolia +, Drymoch- loa sylvatica +, Dryopteris filix-mas +, Galium odoratum +, Impatiens noli-tangere +, Lactuca macrophylla subsp. uralensis + , Lamium album + , Lathyrus vernus + , Parasenecio hastatus + , Pulmonaria obscura + , Stachys sylvatica + , Stellaria holostea + , Viola mirabilis + , Brachypodium sylvaticum r, Bupleurum longifolium r, Carex pediformis subsp. rhizodes r, Epipactis helleborine r, Geum urbanum $\mathrm{r}$, Paris quadrifolia r, Polygonatum multiflorum $\mathrm{r}$.

\section{Hemiboreal eutrophic and mesotrophic forest swamps}

(by A. Solomeshch)

\section{Calamagrostio canescentis-Piceion abietis Solomeshch} all. nov. hoc loco

Synonyms: Calamagrostio canescentis-Piceion abietis Solomeshch in Solomeshch et Grigoriev 1992 (ICPN art. 2b); Crepido paludosae-Piceion abietis Solomeshch in Solomeshch et Grigoriev 1992 (ICPN art. 1)

Holotypus hoc loco: Climacio dendroidis-Piceetum abietis Korotkov 1991 (Korotkov 1991)

Diagnostic species: Picea abies (dominating in the tree layer), Calamagrostis canescens, Cirsium oleraceum, Crepis paludosa, Equisetum sylvaticum, Geum rivale, Luzula pilosa, Oxalis acetosella, Rubus saxatilis, Vaccinium myrtillus, V. vitis-idaea: Mosses: Dicranum scoparium, Plagiothecium laetum, Rhytidiadelphus triquetrus

This vegetation encompasses the Eastern European hemi-boreal eutrophic and mesotrophic forested swamps dominated by Picea abies, Alnus glutinosa and Betula pubescens in the tree layer and Frangula alnus in the shrub layer. They develop on waterlogged peaty gley soils. Their floristic composition represents a mixture of elements characteristic of the Alnetea glutinosae (Calamagrostis canescens, Calla palustris, Dryopteris carthusiana, Galium palustre, Lycopus europaeus, Lysimachia thyrsiflora), the Vaccinio-Piceetea (Picea abies, Lycopodium annotinum, Maianthemun bifolium, Trientalis europaea, Vaccinium myrtillus, V. vitisidaea, Pleurozium schreberi, Hylocomium splendens Dicranum scoparium, Rhytidiadelphus triquetrus), the AlnoPopuletea albae (Corylus avellana, Athyrium filix-femina, Chrysosplenium alternifolium, Cirsium oleraceum, Geum rivale, G. urbanum, Stellaria nemorum, Mercurialis perennis), and the Molinio-Arrhenatheretea (Caltha palustris, Deschampsia cespitosa, Filipendula ulmaria, Lysimachia vulgaris, Ranunculus repens, Scirpus sylvaticus).

Coexistence of species with such a broad spectrum of ecological tolerance is possible due to the mosaic of microhabitats, involving elevated swamp tussocks. Wetland species of the Alnetea glutinosae and the Molinietalia cover 
the area between the tussocks, while mesophilous species of the Vaccinio-Piceetea and the Alnion incanae find their ecological niches on relatively dry tussock tops. Currently this alliance includes two associations - one from Lithuania and one from the Valdai (Novgorod Oblast', Russian Federation). Balevichiene (1988) placed the Lithuanian association in the Alno-Padion Knapp 1942 (recte: Alnion incanae Pawłowski et al. 1928), while Korotkov (1991) included the association from the Valdai in the Alnion glutinosae Malcuit 1929. The distinctiveness of the hemi-boreal coniferous swamps of Eastern Europe and Western Siberia was reflected in the description of a new order - the Calamagrostio canescentis-Piceetalia abietis Solomeshch in Solomeshch et Grigoriev 1992, comprising two alliances - the Crepido paludosae-Piceion abietis Solomeshch in Solomeshch et Grigoriev 1992 (Eastern Europe) and the Calamagrostio langsdorfi-Piceion obovatae Solomeshch in Solomeshch et Grigoriev 1992 (Western Siberia). However, the publication by Solomeshch \& Grigoriev (1992) must be considered as a manuscript, hence the syntaxa were not effectively published (ICPN art. 1). The Siberian alliance was validated by E. Lapshina and placed in the order Calamagrostio purpureae-Piceetalia obovatae Lapshina 2010 (see below).

Here we validate the alliance that represents the Eastern European hemi-boreal swamp forests. The range of this alliance includes Belarus, Ukraine, the northeast of the Russian Plain and the Ural Mts. The Calamagrostio canescentis-Piceion abietis differs from the Siberian alliance in the presence of European species (Picea abies, Alnus glutinosa) and diagnostic species of the Alnion incanae as well as in the absence of Siberian elements such as Picea obovata, Pinus sibirica, Larix sibirica, Calamagrostis purpurea and C. obtusata that are very common and dominant to the east of the Ural Mts.

\section{Nemoral coniferous forests of the Southern Urals and the Southern Siberia}

(by N. Ermakov)

\section{Asaro europaei-Abietetea sibiricae Ermakov, Mucina et Zhitlukhina class. nov. hoc loco}

Synonym: Milio-Abietea Zhitlukhina 1988 (ICPN art. 1)

Non: Milio-Abietea Vorobyov 2014 (ICPN arts. 2b \& 5); Milio-Abietea Lashchinskii 2014 (ICPN arts. 2b \& 5); Milio effusi-Abietetea sibiricae Zhitlukhina ex Lashchinskii et Korolyuk 2015 (ICPN art. 2b \& 5)

Holotypus hoc loco: Abietetalia sibiricae Ermakov (2000) 2006 (Ermakov 2006)
Diagnostic taxa (the same as for the Abietetalia sibiricae): Tree layer: Abies sibirica, Sorbus aucuparia; Herb layer: Aconitum lycoctonum, Anemone altaica, Calamagrostis obtusata, Carex pediformis subsp. macroura, Cerastium pauciflorum, Cirsium helenioides, C. heterophyllum, Corydalis bracteata, Crepis sibirica, Diplazium sibiricum, Dryopteris expansa, D. filix-mas, Erythronium sibiricum, Euphorbia pilosa, Lathyrus gmelinii, Milium effusum, Oxalis acetosella, Paeonia anomala, Parasenecio hastatus, Phegopteris connectilis, Pleurospermum uralense, Ribes petraeum, Stellaria bungeana

These are cool-temperate coniferous and mixed broadleaved-coniferous forests with predominance of nemoral and hemi-boreal floristic elements. They occur on moist rich loamy soils in foothills and low mountains (300$800 \mathrm{~m}$ a.s.l.) of the Southern Urals and in isolated refugial areas of Southern Siberia, in local ultra-humid and weakly continental climate.

The class was ineffectively published (ICPN art. 1) by Zhitlukhina (1988) under the name Milio-Abietea in a manuscript on the vegetation of the Kyga River basin (NE Altai, Russian Federation). The class included one alliance (Milio-Abietion Zhitlukhina 1988; ICPN art. 1) with two associations of dark coniferous forests with tallforb undergrowth. Korotkov (1991), taking into account the important diagnostic role of numerous nemoral herbs and shrubs typical of the European broad-leaved and mixed temperate forests, included the Milio-Abietion Zhitlukhina 1988 in the Fagetalia sylvaticae Pawłowski et al. 1928; this step was also supported by Ermakov (1995, 1998). Later (Ermakov et al. 2000) both the Milio-Abietion Zhitlukhina ex Ermakov et al. 2000 and the Filipendulo ulmariae-Populion tremulae Ermakov in Ermakov et al. 2000 were classified into a new suborder - the Abietenalia sibiricae Ermakov in Ermakov et al. 2000 within the Fagetalia sylvaticae. Ermakov (2006) raised the syntaxonomic rank of the Abietenalia sibiricae to the order level.

Martynenko et al. (2008a) validated the Aconito septentrionalis-Piceion obovatae Solomeshch et al. ex Martynenko et al. 2008 described from the Southern Ural Mts and included the latter also in the Abietetalia sibiricae.

Lashchinskii \& Korolyuk (2015) made an unsuccessful attempt to validate the class Milio-Abietetea, proposing a syntaxonomic scheme that differs from the original concept of the class. The Milio-Abietetea in their sense includes both nemoral mountain forests of the Abietetalia sibiricae and south-boreal forests of Western Siberia classified as a new order - the Carici macrourae-Abietetalia sibiricae. However, the order Carici macrourae-Abietetalia sibiricae, which was designated as type of the class by 
Lashchinskii \& Korolyuk (2015), is invalidly published because its type (the alliance Carici macrourae-Abietion sibiricae) was also not validly published due to the fact that the typus association of the alliance (the Aegopodio podagrariae-Abietetum sibiricae) was invalidly published as well (one of the name-giving species of the association-Aegopodium podagraria - is not present in the type relevé as required by the ICPN art. 16).

Despite the predominance of the boreal Abies sibirica (in the Southern Urals also of Picea obovata) in the tree layer, the Abietetalia sibiricae communities have only weak floristic relationship to the boreal forests as a whole. The character species of the Vaccinio-Piceetea (including boreal dwarf-shrubs, herbs and bryophytes) are absent or rare. The Altai section of the class distribution range includes mixed coniferous (Abies sibirica, Pinus sibirica) and broad-leaved (Populus tremula, Betula pendula, Tilia cordata subsp. sibirica) forests with moderately open canopies (cover of 40-55\%) and well-developed herb layer dominated by nemoral and hemi-boreal herbs (especially tall-forbs and spring geophytes) (Fig. 1). Similar communities of the Southern Urals are characterised by spruce (Picea obovata) with admixture of Abies sibirica, Tilia cordata, Acer platanoides and Ulmus laevis. On the whole, the floristic composition of the Abietetalia sibiricae is closer to the Carpino-Fagetea than to the VaccinioPiceetea. However, the Carpino-Fagetea is a class dominated by deciduous trees. Therefore, we consider the nemoral coniferous forests of the Southern Urals and Siberia as a class in its own right, showing peculiar floristic, physiognomic and ecological features where numerous species of North Eurasian and North Asian distribution play an important role. To avoid confusion with the Milio-Abietetea sibiricae sensu Lashchinskii \& Korolyuk (2015), we choose the new name Asaro europaei-Abietetea sibiricae for this class.

The Asaro europaei-Abietetea sibiricae have a disjunctive distribution range occupying the Southern Ural

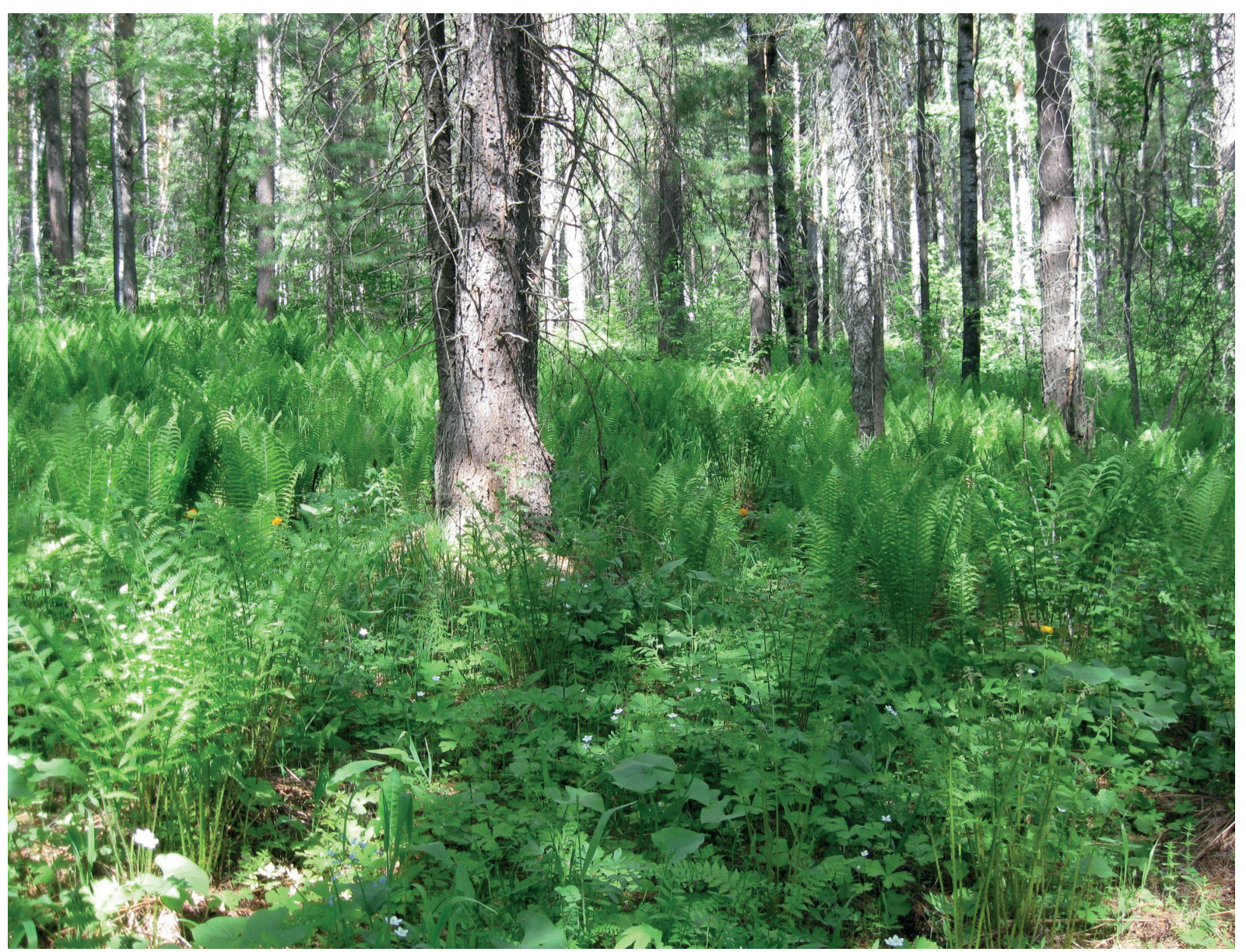

Figure 1: Nemoral coniferous forest of the Milio-Abietion (Abietetalia sibiricae, Asaro europaei-Abietetea sibiricae) in the Western Sayan Mts., Southern Siberia.

Slika 1: Iglasti gozd zveze Milio-Abietion (Abietetalia sibiricae, Asaro europaei-Abietetea sibiricae) na gorovju Zahodni Sayan, južna Sibirija. 


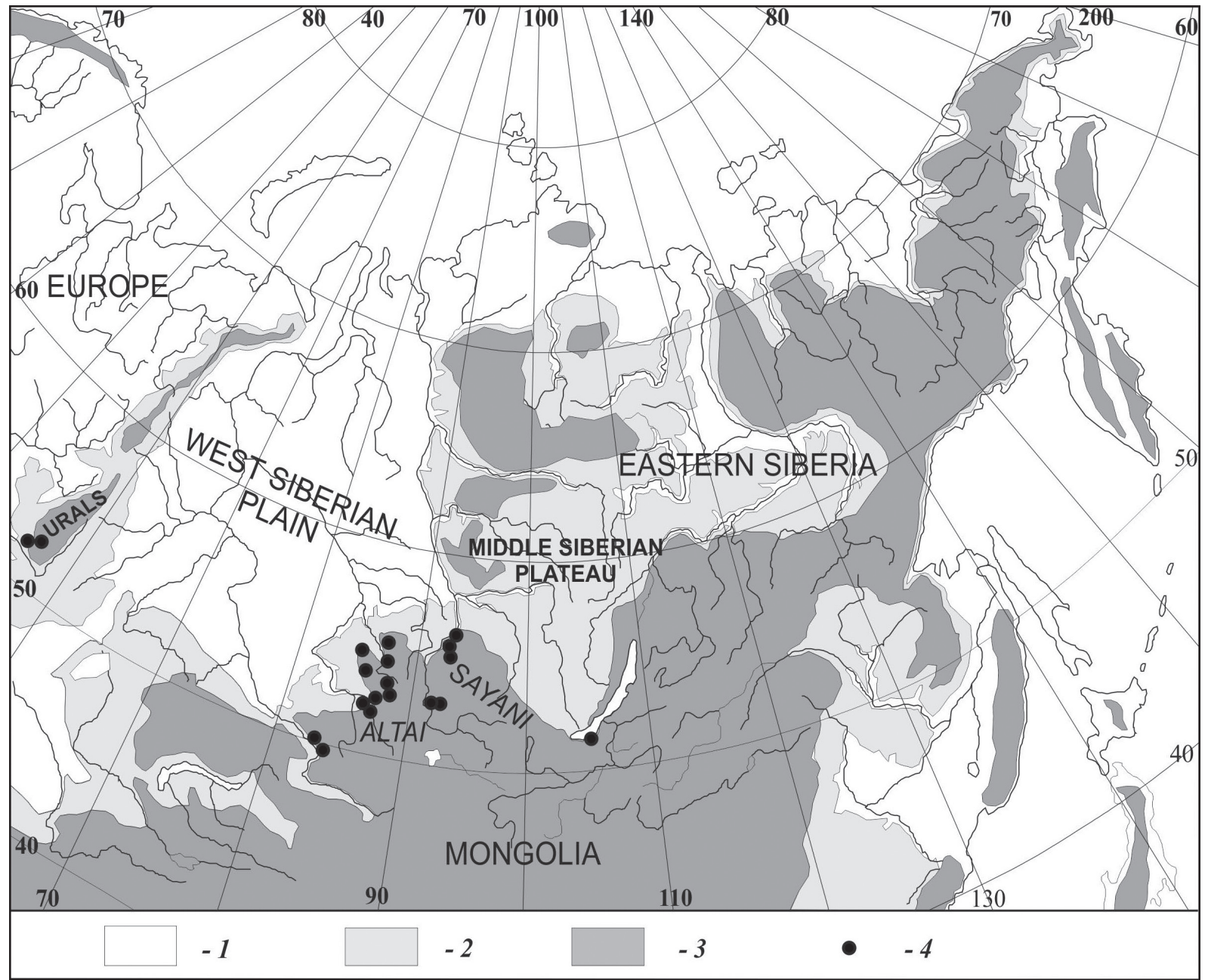

Figure 2: Distribution of the Asaro-Abietetea forests. 1: Plains and lowlands (altitudes of 10-200 m); 2: Lower plateaus and elevated plains (altitudes of 200-800 m); 3: Plateaus and mountains (altitudes of 800-4000 m); 4: Location of relevés of the Asaro-Abietetea forests.

Slika 2: Razširjenost gozdov razreda Asaro-Abietetea. 1: Ravnine in nižine (10-200 m nad morjem); 2: Nižji platoji in višjeležeče ravnine (200-800 m nad morjem); 3: Platoji in gorovja (800-4000 m nad morjem); 4: Lokacije popisov gozdov razreda Asaro-Abietetea.

(together with adjacent parts of elevated plains) and the foothills of the Altai-Sayan mountain system characterised by locally ultra-humid, weakly continental climate at altitudes of 300-800 m (Fig. 2). The link of the Asaro europaei-Abietetea sibiricae forests to the ultra-humid climate explains the main ecological and floristic features of this class: a relatively moderate temperature of the coldest month (January mean: $-16^{\circ} \mathrm{C}$ ) and large amount of winter precipitation $(275 \mathrm{~mm})$, resulting in the formation of a snow cover of up to $1.5 \mathrm{~m}$ that prevents freezing of the soil and protects herbs from damaging impacts of frost. The environments are favourable for species of the European broad-leaved forests (Actaea spicata, Asarum europaeum, Brachypodium sylvaticum, Bromopsis benekenii, Carex sylvatica, Daphne mezereum, Drymochloa sylvatica, Dryopteris filix-mas, Galium odoratum, Loni- cera xylosteum, Polystichum braunii, Sanicula europaea, Schenodorus giganteus). These species have disjunctive relic ranges in the Southern Siberia. At the same time the climatic peculiarities support the occurrence of Euro-Siberian and North Asian tall forbs characteristic of subalpine forests. This tall-forb group includes Aconitum lycoctonum, Angelica sylvestris, Bupleurum longifolium, Brunnera sibirica, Parasenecio hastatus, Calamagrostis purpurea subsp. langsdorfi, Cirsium heterophyllum, Delphinium elatum, Euphorbia pilosa, Filipendula ulmaria, Geranium sylvaticum, Lathyrus gmelinii, Lilium martagon, Matteuccia struthiopteris, Milium effusum, Paeonia anomala, Pleurospermum uralense, Senecio nemorensis, Veratrum lobelianum and Saussurea latifolia. 
Xero-thermophilous broad-leaved ravine forests of SE Europe

(by A. Čarni)

Košir et al. (2008) presented an analysis of ravine broadleaved forests of SE Europe and adjacent areas of Central Europe, revealing that the major division in the ravine forests was between mesophilous and xero-thermophilous communities while the further division of these two major groups was spanning a geographical gradient between Central European and SE European syntaxa. Accordingly, four main types of ravine forests were treated at the suballiance level and classified within the broadly conceived Tilio-Acerion Klika 1955.

Since the EuroVegChecklist follows a narrower concept of classes, orders and alliances, the broad-leaved ravine forests are treated as an order of its own right, the Aceretalia pseudoplatani Moor 1976. Thus, the suballiances of Košir et al. (2008) should be classified as separate alliances, with the Tilio-Acerion s. str. including the mesophilous communities and the Melico-Tilion platyphylli Passarge et G. Hofmann 1968 including the xero-thermophilous communities of Central Europe. The mesophilous unit of SE Europe is known as the FraxinoAcerion Fukarek 1969 (corresponding to the Lamio orvalae-Acerenion in Košir et al. 2008) while the xero-thermophilous unit, originally described as the suballiance Ostryo-Tilienion by Košir et al. (2008) lacks a legitimate name at the alliance level. Since the Fraxino-Acerion was validly described by Fukarek (1969), here we deal only with the xero-thermophilous ravine forests of SE Europe.

Ostryo carpinifoliae-Tilion platyphylli (Košir et al. 2008) Čarni stat. nov. hoc loco

Basionym: Ostryo carpinifoliae-Tilienion platyphylli Košir et al. 2008 (Košir et al. 2008: 339)

Diagnostic species: Acer campestre, Clematis vitalba, Crataegus monogyna, Cyclamen purpurascens, Dapne laureola, Dioscorea communis, Festuca heterophylla, Fraxinus ornus, Hedera helix, Helleborus odorus, Hepatica nobilis, Ligustrum vulgare, Melica uniflora, Melittis melissophyllum, Ostrya carpinifolia, Primula vulgaris

The Ostryo-Tilion includes the xero-thermophilous broad-leaved ravine forests of the Apennine and Balkan Peninsulas, especially the regions characterised by submediterranean climate. The diagnostic species are partly shared with the thermophilous deciduous oak forests and partly with the thermophilous beech forests. The occurrence of this unit on both sides of the Adriatic Sea points upon shared climatic conditions and florogenetic history of both Peninsulas during the Quaternary (Košir et al. 2008).

\section{Evergreen oak forests of Cyprus}

(by E. Bergmeier)

The 'Quercion alnifoliae' was proposed by Barbero \& Quézel (1979: 22). However, the name was invalid according to art. $2 \mathrm{~b}$ ICPN because the two associations in the original diagnosis ('association à Quercus alnifolia et Pinus brutia' and 'association à Quercus alnifolia et Crepis frasii') were both invalidly published due to the form of the name (ICPN art. 3h) and the failure to designate the nomenclature type (ICPN art. 5). The name 'Quercion alnifoliae' remained invalid in Quézel et al. (1993) because the name 'Querco alnifoliae-Pinetum brutiae Barbero et Quézel 1979' designated as the type was invalid due to the missing type relevé for the type association. Therefore we validate the name Quercion alnifoliae here as follows:

\section{Quercion alnifoliae Barbero et Quézel ex Bergmeier,} Mucina et Theurillat all. nov. hoc loco

(Quercetalia calliprini, Quercetea ilicis)

Diagnostic taxa: Trees: Quercus alnifolia, Pinus brutia; Herbs and low shrubs: Crepis fradii, Erophaca baetica subsp. orientalis Helichrysum italicum subsp. italicum, Lecokia cretica, Salvia fruticosa, Stellaria cilicica, Teucrium kotschyanum

Holotypus (hoc loco) of the alliance: Querco alnifoliae-Pinetum brutiae Barbero et Quézel ex Bergmeier, Mucina et Theurillat ass. nov. hoc loco

Holotypus (hoc loco) of the association: Barbero \& Quézel (1979: 23, Table 7, rel. 7).

According to its current circumscription, as suggested by Barbero \& Quézel (1979), the Quercion alnifoliae comprises sclerophyllous woodlands on igneous rock of Mt. Troodos, Cyprus, found at altitudes spanning (500-) 700-1200 (-1300) m. Common woody species are $A r-$ butus andrachne, Lonicera etrusca, Pinus brutia, Pistacia terebinthus subsp. palaestina and the Cyprian endemic Quercus alnifolia. Pinus brutia, Quercus alnifolia and, more rarely, Acer obtusifolium and Cedrus libani subsp. brevifolia may be the dominanating trees. The Quercion alnifoliae is an alliance endemic to the island of $\mathrm{Cy}$ prus, but shares many species with woody formations of Quercus, Pinus, Pistacia and Styrax elsewhere in the Eastern Mediterranean. 


\section{Acknowledgements}

We would like to thank Milan Chytrý for valuable comments on a previous version of the manuscript. N. Ermakov would like to acknowledge support by the Russian Foundation for Basic Sciences (Grant 15-14-04928).

\section{References}

Barbero, M. \& Quézel, P. 1979: Contribution à l'étude des groupements forestiers de Chypre. Documents Phytosociologiques N.S. 4: 9-34.

Bulokhov, A.D. \& Solomeshch, A.I. 2003: Ekologo-floristicheskaya klassifikatsiya lesov Yuzhnogo Nechermozeml'ya Rossii. (Ecologicfloristic classification of the forests of the Southern Nechernozem Region of Russia.) Bryanskii Gosudarstvennyi Universitet, Bryansk. (in Russian)

Balevichiene, Yu. 1988: Rastitel'nost'. (Vegetation.) In: Rastitel'nyi pokrov Natsional'nogo parka Litovskoi SSR. (Vegetation cover of the National Park of the Lithuanian SSR.) Institut botaniki Akademii nauk Litovskoi SSR, Vil'nius, pp.13-81. (in Russian)

Chytrý, M. 1997: Thermophilous oak forests in the Czech Republic: Syntaxonomical revision of the Quercetalia pubescenti-petraeae. Folia Geobotanica et Phytotaxonomica 32: 221-258.

Chytrý, M., Danihelka, J., Horsák, M., Kočí, M., Kubešová, S., Lososová, Z., Otýpková, Z., Tichý, L., Martynenko, V.B. \& Baisheva, E.Z. 2010: Modern analogues from the Southern Urals provide insights into biodiversity change in the early Holocene forests of Central Europe. Journal of Biogeography 37: 767-780.

de Bolòs, O. 1979: Le Sambuco-Salicion capreae en Catalogne. Documents Phytosociologiques N.S. 4: 69-74.

Ermakov, N.B. 1995: Klassifikatsiya sibirskikh gornykh subnemoral'nykh melkolistvenno-temnokhvojnykh i lipovykh lesov. (Classification of Siberian montane sub-nemoral smallleaved-dark coniferous and lime forests.) In: Kupriyanov A.N. (ed.), Botanicheskiye issledovaniya Sibiri i Kazakhstana. (Botanical studies in Siberia and Kazakhstan.) Sbornik nauchnykh statei Gerbariya Altaiskogo Universiteta. Izd. Altaiskogo Universiteta, Barnaul, pp. 30-91. (in Russian)

Ermakov, N., 1998: The Altaian relict subnemoral forest belt and the vegetation of pre-Pleistocene mountainous landscapes. Phytocoenologia 28: 31-44.

Ermakov, N. 2006: Analiz sostava tsenoflor kontinental'nykh gemiboreal'nykh lesov Severnoi Azii. (Analysis of floristic composition of hemiboreal forests of Northern Asia.) Turczaninowia 9(4): 5-92. (in Russian)

Ermakov, N.B., Korolyuk, A.Y. \& Lashchinskiy, N.N. 1991: Floristicheskaja klassifikacija mezofil'nyh travjanyh lesov Juzhnoj Sibiri. (Floristical classification of mesophylic grass forests of the South Siberia.) Central'nyj sibirskij botanicheskij sad, Sibirskoe otdelenie Akademii nauk SSSR, Novosibirsk. (in Russian)

Ermakov, N., Dring, J. \& Rodwell, J. 2000: Classification of continental hemiboreal forests of North Asia. Braun-Blanquetia 28: $1-131$
Fukarek, P. 1969: Prilog poznavanju biljnosocioloških odnosa šuma i šibljaka nacionalnog parka Sutjeska. Posebna izdanja ANU BiH 11, Odjelenje prirodnih i matematičkih nauka 3: 189-291.

Géhu, J.-M. 2006: L’ordre des Betulo pendulae-Populetalia tremulae en France. Bulletin de la Société botanique du Centre-Ouest, N.S. 36: 297-302.

Gorchakovskii, P.L. 1972: Shirokolistvennye lesa i ikh mesto v rastitel'nom pokrove Yuzhnogo Urala. (Shirokolistvennye lesa i ikh mesto v rastitel'nom pokrove Yuzhnogo Urala. (Broadleaved forests and their place in vegetation cover of the Southern Urals.) Nauka, Moskva. (in Russian)

Korotkov, K.O. 1991: Lesa Valdaya. (Forests of Valday.) Nauka. Moskva. (in Russian)

Košir, P., Čarni, A. \& Di Pietro, R. 2008: Classification and phytogeographical differentiation of broad-leaved ravine forests in southeastern Europe. Journal of Vegetation Science 19: 331-342.

Lapshina, E.D. 2010: Rastitel'nost' bolot yugo-vostoka Zapadnoi Sibiri. (Vegetation of mires of the south-east of Western Siberia.). NGU (Novosibirsk State University), Novosibirsk. (in Russian)

Lashchinskii, N.N. \& Korolyuk, A.Yu. 2015: Sintaksonomiya temnokhvojnykh zonal'nykh lesov yuzhnoi tajgi Zapadno-Sibirskoi ravniny i gumidnykh nizkogorij Altae-Sayanskoi gornoi oblasti. (Syntaxonomy of the zonal dark coniferous forests of the southern taiga of the Western Siberian Plain and humid low mountain of the AltaiSayan mountain region). Rastitel'nost' Rossii 26: 85-107. (in Russian)

Martynenko, V.B, Shirokikh, P.S. \& Muldashev, A.A. 2008a: Sintaksonomiya lesnoi rastitel'nosti. (Syntaxonomy of the forest vegetation.) In: Mirkin, B.M. (ed.), Flora i rastitel'nost' Yuzhno-Ural'skogo gosudarstvennogo zapovednika. (Flora and vegetation of the Yuzhno-Uralski State Natural Reserve.) pp. 124-240. Gilem, Ufa. (in Russian)

Martynenko, V.B., Shirokikh, P.S., Muldashev, A.A. \& Solomeshch, A.I. 2008b: O novoi assotsiatsii ostepnennykh dubrav na Yuzhnom Urale. (On the new association of steppe oak forests on the South Urals.) Rastitel'nost' Rossii 13: 49-60. (in Russian)

Martynenko, V.B., Yamalov, S.M., Zhigumov, O.Y. \& Filinov, A.A. 2005: Rastitel'nost' gosudarstvennogo prirodnogo zapovednika "Shulgan-Tash". (Vegetation of the State Nature Zapovednik "ShulganTash".) Ufa, Gilem. (in Russian)

Mirkin, B.M. \& Solomeshch, A.I. 1990: Predvaritel'nii prodromus rastitel'nosti SSSR. IV. Prilozhenie 1. (Preliminary prodromus of the USSR vegetation. IV. Supplement 1.) Manuscript, VINITI 15.03.90, N.1436-B90, Moskva. (in Russian)

Quézel, P., Barbero, M. \& Akman, Y. 1993: Typification de syntaxa décrits en région méditerranéenne orientale. Ecologia Mediterranea 18 ('1992'): 81-87.

Rivas-Martínez, S. 1965: Esquema de la vegetación potencial y su correspondencia con los suelos de la España peninsular. Anales del Instituto Botánico A. J. Cavanilles 22: 343-404.

Rivas-Martínez, S., Díaz, T. E., Fernández-González, F., Izco, J., Loidi, J., Lousã, M. \& Penas, A. (eds.) 2002: Vascular plant communities of Spain and Portugal. Addenda to the syntaxonomical checklist of 2001. Itinera Geobotanica 15: 5-922.

Schubert, R., Jäger, E.J. \& Mahn, E.-G. 1979: Vergleichende geobotanische Untersuchungen in der Baschkirischen ASSR. Hercynia N.F. 16: 206-263. 
Shirokikh, P.S., Sultangareeva, L.A. \& Martynenko, V.B. 2010: Lesnaya rastitel'nost'. (Forest vegetation.) In: Mirkin, B.M. (ed.), Flora i rastitel'nost' Natsional'nogo Parka "Bashkiria" (sintaksonomia, antropogennaya dinamika, ekologicheskoe zonirovanie). (Flora and vegetation of the National Park "Bashkiria" (syntaxonomy, antropogenic dynamics, ecological zonation).) Ufa, Gilem, pp. 85-154. (in Russian)

Solomeshch, A.I. \& Grigoriev. I.N. 1992. Syntaxonomiya lesov Yuzhnogo Urala. VII. Zabolochennye lesa. (Syntaxonomy of the forest of the Southern Urals. VII. Swamp forests.) Manuscript, VINITI 11.12.92., N 3495-B92, Moskva. (in Russian)

Solomeshch, A.I., Grigoriev, I.N. \& Khaziakhmetov, R.M. 1989a: Sintaksonomiya lesov Yuzhnogo Urala. III. Poryadok Quercetalia pubescentis. (Syntaxonomy of the forest of the Southern Urals. III. Order Quercetalia pubescentis.) Manuscript, VINITI 12.10.89, N 6233-B89, Moskva. (in Russian)

Solomeshch, A.I., Grigoriev, I.N. \& Khaziakhmetov, R.M. 1989b: Sintaksonomiya lesov Yuzhnogo Urala. IV. Poryadok Fagetalia sylvaticae. (Syntaxonomy of the forest of the Southern Urals. IV. Order Fagetalia sylvaticae.) Manuscript, VINITI 12.10.89, N 6234-B89, Moskva. (in Russian)

Solomeshch, A.I., Grigoriev, I.N., Khaziakhmetov, R.M. \& Baisheva, E.Z. 1993: Sintaksonomiya lesov Yuzhnogo Urala. V. Smeshannye khvoino-shirokolistvennye lesa. (Syntaxonomy of the forest of the Southern Urals. V. Mixed conifer-broadleaved forests.) Manuscript, VINITI 02.06.93, N 1464-B93, Moskva. (in Russian)
Solomeshch, A.I., Grigoriev, I.N., Muldashev, A.A. \& Alimbekova, L.M. 1994: Rastitel'nost' khrebta Shaitan-Tau. (Vegetation cover of the Shaitan-Tau mountain ridge.) In: Dubrovnaya lesostep' na khrebte Shaitan-Tau i voprosy ee okhrany. (The oak forest-steppe of the Shaitan-Tau mountain ridge and its conservation.) Ufimskii Nauchnii Tsentr' Rossiiskoi Akademii Nauk, Ufa, pp. 27-96. (in Russian)

Solomeshch, A.I., Martynenko, V.B. \& Zhigunov O.Yu. 2002: Caragano fruticis-Pinion sylvestris - novyi soyuz ostepnennykh sosnovo-listvennichnykh lesov Yuzhnogo Urala. (Caragano fruticisPinion sylvestris, a new alliance of the thermophilous pine-larch forests of the Southern Urals.) Rastitel'nost' Rossii 3: 42-62. (in Russian)

Weber, H.E., Moravec, J. \& Theurillat, J.-P. 2000: International Code of Phytosociological Nomenclature. $3^{\text {rd }}$ edition. Journal of Vegetation Science 11: 739-768.

Zhitlukhina, T.I. 1988: Sintaksonomiya lesov i subal'piiskikh lugov Kyginskogo ekologicheskogo profil'ya (yuzhnaya chast' Teletskogo ozera). (Syntaxonomy of the forests and subalpine meadows of the Kyginsky ecological transect (southern part of the Teletskoye Lake). Manuscript, VINITI 21.03.88, N2146-V88, Moskva. (in Russian) 